\title{
Discussion on English Teaching of MICE Major in Colleges and Universities
}

\author{
Hui Li \\ Department of Tourism Management \\ Zhuhai College of Jilin University \\ Zhuhai, China
}

\begin{abstract}
MICE English, as a core course of MICE major, has been paid more and more attention with the improvement of the international level of MICE industry in China. However, the current MICE English teaching lags behind the development of the MICE industry. This paper makes a preliminary study of some problems in MICE English teaching, and puts forward some suggestions on the innovation of teaching methods of MICE English, the construction of teaching staff, and the improvement of the compilation of teaching materials.
\end{abstract}

Keywords-MICE English; MICE talent; suggestion

\section{INTRODUCTION}

With the all-round promotion of economic globalization, the rapid development of science and technology, economy in China develops rapidly and international exchanges become increasingly frequent, so MICE industry has become a new economic growth point in China as a multi-functional "sunrise industry in the 21st century", which integrates business activities, conference display, sightseeing, external publicity, and cultural exchanges and so on. In the changing international market environment, the MICE industry is developing towards internationalization, specialization and high-tech. Therefore, in order to make China's MICE industry in line with the international MICE industry, in practical work, in addition to requiring solid professional knowledge of exhibition practitioners, more important is their English practical ability.

The development of exhibition industry in China is fast, but it starts late. Compared with that of the developed countries, there is still a big gap. This gap is mainly reflected in the lack of exhibition professionals and low quality of professionals. The main reason is that the MICE teaching in China lags behind the rapid development of the MICE industry, especially the teaching of MICE English. In order to cultivate talents who meet the requirements of the development of MICE industry, some universities have set up MICE English courses one after another in recent years, but how to make the student really learn the MICE English actually is a question which is worth to explore.

\section{PResent Situation of MiCE ENGLISH TEACHING}

With the constant development of market economy, especially the impact of China's entry into WTO on English education, the inadaptability of professional English teaching to the society is becoming more and more prominent. It mainly presents as: the inadaptability of the quality of teachers, curriculum, teaching content and methods, and students' practical English application ability and so on. Many employers hope that students have good listening and speaking ability, namely the practical application ability of English. Excellent compound practical English talents are urgently needed. However, the professional English courses offered by most of the colleges and universities in China ignore the actual needs of the students and the society for English talents, leading to the students' poor ability to use professional English, which cannot meet the needs of all kinds of communication in the industry. The fundamental reason for this mismatch is that we do not focus on improving students' ability to use English in practice. And because of the short development of MICE in China, the MICE English teaching model in colleges and universities is still in the exploratory stage. There are many problems:

\section{A. Too Much Emphasis Is Put on Writing and Reading}

First of all, due to the over-emphasis placed on the importance of passing rate of CET-4 and CET- 6 in teaching of MICE English, the basic English teachers use part of class time for tutoring, which results in the decrease of the study of professional English and the weakening of the importance of professional English in the students' mind and makes the students' ability of professional English fail to meet the requirements and standards of the profession, and even deviate from the practice. And the teaching model of professional English is also affected by basic English, especially the teaching methods for the purpose of passing exam, so professional English has continued to focus only on writing and reading ability. Most of the graduates of MICE majors generally have a higher level of English reading than listening and speaking ability, forming "dumb English" which can only read, but can't understand or speak. Although teachers in the teaching process put forward the requirements of strengthening oral English and listening, but there is no special English listening and speaking courses. 


\section{B. Teaching Methods Are Limited to the Traditional Model}

First, the arrangement of class hour is unreasonable, with too much explanation and too little practice, which inevitably will ignore the student's initiative and the creativity. It is difficult to create a professional English scene atmosphere to let the student master and use the professional English effectively in the simulation MICE environment. Second, the teaching is limited to the text analysis of the textbooks, but lacks a deep understanding of the exhibition practice. Third, the teaching method lacks flexibility and interest. The teaching method of MICE English is similar to general basic English teaching, which does not give full prominence to the specialty and application, so the students' learning enthusiasm is insufficient. Even if their achievement is good during the learning period, there are still many problems and obstacles in the practical application.

\section{Shortage of Teachers}

Good teacher is the guarantee to improving the quality of teaching. However, as a relatively new course, the training of teachers for MICE English is relatively backward. At present, there is a shortage of teachers who have both English teaching experience and exhibition experience. Most of the MICE English teachers in colleges and universities are from the original basic English course teachers. Although they are familiar with the general rules and methods of basic English teaching and have obvious advantages in basic English teaching, it is difficult for them to deepen MICE English teaching because of their lack of MICE practice, MICE background knowledge and even specific understanding of the rules of MICE operation. In addition, there are also a small number of exhibition professionals undertaking English teaching work. Although they are familiar with exhibition professional knowledge, and have a wealth of practical experience, but they don't have solid English professional knowledge, thus restricting and affecting the improvement of students' English level.

\section{The Teaching Materials of MICE English Are not Systematic Enough}

From the perspective of the existing MICE English textbooks, first of all, there are many MICE English textbooks in the domestic market. However, there are few textbooks that can cover the professional knowledge of MICE and have enough practicality with moderate difficulty and the reasonable arrangement of teaching content. Second, there are rare extracurricular learning reference materials and books, audio-visual materials and audio-visual teaching software. At the same time, the introduction of the original MICE English teaching material is not enough, which cannot be in line with the latest international teaching material system. In addition, many teaching materials are compiled by teachers engaged in basic English teaching, resulting in a strong theoretical material, which is difficult to contact the actual needs of work, and lack practice seriously, so students also feel boring. In addition, some MICE interpretation teaching materials are mainly composed of industry-related real-scene English dialogue. Although they can give students some simulation and training of the scene, the difficulty of content is not the same, and the lack of systematic professional knowledge accumulation make it difficult for students to adapt.

\section{STRATEGIES AND SUGGESTIONS ON MICE ENGLISH TEACHING}

\section{A. Intensifying the Teaching of Listening and Speaking in MICE English}

The first thing to learn English is to learn the listening and speaking, and combine with written language, instead of changeless written English. Therefore, learning English should first learn to speak. The first task of English teaching is to organize effective listening and speaking training, which is often neglected by many teachers.

Good English atmosphere should be created: the teacher can vigorously promote full English teaching in the specialized English listening and speaking class to create a pure English teaching atmosphere with all efforts from the question to the explanation. In addition, in the choice of teaching materials, dry and single teaching material should no longer be used while the material in people's daily life can be chosen to facilitate the practice of listening and speaking.

\section{B. Highlighting the Cultivation of Practical Language Application Ability}

Language is a tool of communication. For the students, only if they master the basic knowledge of English and have the ability to communicate in English, can they really learn English. The aim of MICE English teaching in colleges and universities should be to cultivate the students' ability to use the language in practice. They should emphasize the practicality and pertinence of the teaching content, and organically combine the basic ability of language with the training of actual ability of foreign-related communication. We should fully realize that MICE English teaching must meet the social needs of students and the practicality of learning. Emphasis should be placed on the effective combination of vocational training and language training. In addition to a definite purpose, it is also necessary to analyze the possible situation where learners may use English in the future to find out what knowledge and skills they need in the process of communication, so as to organize teaching in a targeted way and open up a broad channel for students' employment.

\section{Strengthening the Construction of the Teaching Staff}

The quality of teachers determines the professional construction and professional teaching level. Thus, it is necessary to strengthen the academic exchanges between colleges and universities in MICE English teaching, actively carry out the research of MICE English teaching, and vigorously improve the quality of MICE English teaching. At the same time, we should take various measures to cultivate and introduce talents, actively invite people from exhibition industry to join in the team of teachers and implement cooperation between school and enterprise, so that we can establish a team of English teachers who are rich 
in professional English teaching experience, with high English level and professional knowledge of exhibition as soon as possible. In order to keep up with the rapid development of the industry, it is necessary to establish a communication system with the industry, which is "sending teachers to study and investigate in enterprises, and invite experienced enterprise managers to give special reports to teachers and students." Professional teachers are encouraged to take advantage of the opportunity of visiting interns to talk to and communicate with managers at all levels in practice units, to investigate and understand the working needs of exhibition enterprises and screen and refine information to transplant the innovative ideas, management systems, quality requirements and service standards that embody the advanced enterprise culture into the contents of the lectures. At the same time, the typical cases, management system, management methods, staff training and other content of excellent exhibition enterprises can be directly used in the classroom teaching, so as to make students feel in an atmosphere of corporate culture. At the same time, we should establish close contact with enterprises, invite professional managers of well-known enterprises to give special reports for school regularly, understand students' needs in theoretical knowledge and practical ability face to face, and revise, supply and perfect the teaching content in time according to the needs of enterprises, so as to keep up with the development of enterprises.

\section{Making Innovation in Teaching Methods}

In teaching, we should change the traditional way of teaching and make full use of advanced equipment such as Internet, electronic reading room, multimedia classroom, teaching electronic software and so on in the context of English teaching to develop practical teaching, so that students can understand the standardized service and management of exhibition enterprise through network, video and picture, and the latest development of international exhibition industry. Thus we can arouse students' learning enthusiasm, and improve the vividness and intuitiveness of teaching.

To fully mobilize the enthusiasm of the students, we can adopt the teaching method of discussion and interaction after class and develop more scene simulation activity and competition to guarantee the improvement and exertion of students' strain force and the creativity. Simultaneously, we can also combine with the specialized curriculum to organize student to visit the exhibition enterprise or the exhibition scene and practice there, thus increasing student's perceptual understanding, strengthening the scene sense and the role consciousness and making the student learn better and practice well. The teacher can also use the video camera to record the students' actual combat rehearsal, and comment and guide the performance of the students one by one through the playback to deepen students' memory and improve the quality of teaching.

\section{E. Perfecting Teaching Materials of MICE English}

Good teaching material is a basic premise to ensure highquality teaching. The ultimate goal of perfecting the teaching material of MICE English is to compile the teaching material which is suitable for the development of MICE in China, the students and the characteristics of MICE in China. It should also have the characteristics of comprehensiveness, living, interest, reality, practicality and inquiry. Attention should be paid to the following points in the compilation of MICE textbooks:

1) Getting out of the classroom and combining with the actual industry: MICE major is a work paying attention to practical operation and application ability. Therefore, our demand for the content of professional English textbooks mainly focuses on the practical application of MICE, including listening and speaking ability, MICE communication, situational dialogue, and industry terms and so on. Therefore, teachers should actively, timely understand the current and future socio-economic development characteristics and direction, actively enter the enterprise, and integrate with MICE industry integration to inject fresh breath full of the characteristics of the times to MICE English classroom. Teaching materials should be close to reality, close to the work of MICE industry to enhance the competitiveness of students' employment and lay a solid professional foundation for student to enter MICE industry.

2) Consulting professionals to ensure the authority of the teaching materials: The most important function of teaching material is to impart the knowledge of a subject to the students systematically. Therefore, the authority of the textbook is very important. In order to link MICE English teaching with the major, we can combine the teaching experience of basic English teachers and the professional knowledge of MICE professionals to determine the content structure of MICE English school-based textbooks, and then compile the textbooks which are full of professional features and meet the employment needs of students.

3) Using scientific and effective methods, and adopting a feasible arrangement system: The compilation of MICE English textbooks should be based on the needs of students, combine with the actual situation of the industry, use scientific and effective methods, adopt a highly operable arrangement system in the classroom, and adhere to the concept of "people-oriented" and "keeping pace with the times". First of all, in the actual operation of MICE industry, it main needs the scene conversation, exhibition terms, commonly used sentence patterns, and English communication skills. Therefore, in the compilation of teaching materials, we should focus on developing students' language communication skills, and combine with exhibition professional skills training, oral expression skills and professional knowledge. Second, the content of the textbook should be knowledgeable and contemporary, covering a wide range of areas, with concise language and rich vocabulary, to broaden the vision of students, and conform to the personnel requirements of fast development of MICE industry. Thirdly, the teaching materials of MICE 
should involve the whole process of MICE, which not only need to be rich in content, but also include practical skills and reliable materials, so that students can systematically understand the professional knowledge and master the necessary professional skills under the consciousness of English. Fourth, the realization form of teaching materials should be in a variety of forms, and it had better improve audio-visual, multimedia and other series of reference and supporting teaching materials.

\section{CONCLUSION}

The development of exhibition industry in China is fast, but it starts late. Compared with that of the developed countries, there is still a big gap. This gap is mainly reflected in the lack of exhibition professionals and low quality of professionals. Especially in the aspect of internationalization, the professional English level of MICE workers is more backward, mainly reflected in the relatively poor professional basis of high English level and the poor English ability of high professional level. How to improve the English level and comprehensive ability of the professional MICE talents in the future training process is a very important issue. The training and strengthening of teachers, the improvement of teaching methods and the compilation of high-quality teaching materials can all improve this situation, which needs the joint efforts of scholars and industry participant. Therefore, the cultivation of professional talents in MICE industry, especially the improvement of the professional English level of practitioners, needs closer cooperation between schools and enterprises and integration of production and teaching.

\section{REFERENCES}

[1] Bi Yan, Yin Cuifang. Exploring the Teaching Reform of professional English Based on Applied Ability--Taking MICE English as an Example [J]. Education Forum, 2016 (21): 69-70. 毕妍, 耂翠芳. 以应 用能力为导向的专业英语教学改革探索——以会展英语为例 $[\mathrm{J}]$. 教育教学论坛,2016(21):69-70.

[2] Liu Nian. Discussion on teaching of MICE English course based on TBLT teaching model [J]. Statistics and Management, 2015 (11): 183-184. 刘念.基于 TBLT 教学模式的会展英语课程教学探讨 [J]. 统计与管理,2015(11):183-184.

[3] Wang Li. Features of MICE English and study on Its Translation [J]. Journal of Heilongjiang College of Education, 2015, 34 (07): 132-133. 王莉. 会展英语特点及其翻译方法初探 [J]. 黑龙江教育学院学 报,2015,34(07):132-133.

[4] Gan Lihua. A Study on the Mode and Path of MICE Talents Training in the Context of Industrial Upgrading--A Case Study of Shunde District, Foshan [J]. Journal of Hubei University of Economics (Humanities and Social Sciences Edition), 2014, 11 (04): 70-71. 甘丽 华.产业升级背景下会展英语人才培养模式及路径研究——以佛 山顺德区为例 [J]. 湖北经济学院学报 (人文社会科学 版),2014,11(04):70-71.

[5] Chen Jing, Shi Wenna. Discussion on Microlecture Teaching Design of ESP Course Based on Work Task--Taking Exhibition English Booth Reservation as an Example [J]. Journal of Hunan Institute of Science and Technology, 2016, 37 (04): 158-160.陈婧,史雯娜.基于 工作任务的 ESP 课程微课教学设计探讨- - 以 《会展英语》 “展位预订” 为例 [J].湖南科技学院学报,2016,37(04):158-160

[6] Zhang Xiaoying. Research on the Cultivation of Cross-cultural Ability in MICE Teaching in Higher Vocational Education in the Global Context [J]. Comparative Study of Cultural Innovation, 2017,
1 (13): 101-102. 张晓颖.全球背景下的高职会展英语教学跨文化能 力培养研究[J].文化创新比较研究, 2017,1(13):101-102.

[7] Huang Xiaotong. An Empirical Study of English Major Curriculum Based on Mobile Learning--A Case Study of MICE English [J]. Journal of Shenzhen Polytechnic, 2016, 15 (06): 74-78. 黄晓肜.基于 移动学习的英语专业课程实证研究——以 《会展英语》为例 $[\mathrm{J}]$. 深圳职业技术学院学报,2016,15(06):74-78. 